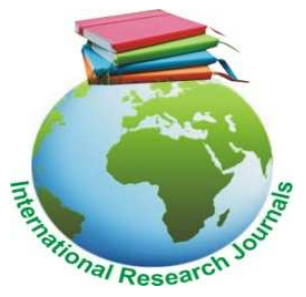

Journal of Medicine and Medical Sciences Vol. 8(4) pp.048-053, June 2017

DOI: http:/dx.doi.org/10.14303/jmms.2017.037

Available online http://www.interesjournals.org/JMMS

Copyright (C) 2017 International Research Journals

\title{
Prevalence and distribution of the use of medicated glasses and refractive errors among Nigerian youths in a tertiary institution in Rivers State Nigeria
}

\author{
${ }^{* 1}$ Aguwa U. S., ${ }^{1}$ Ovie F.O., ${ }^{2}$ Onoikhua E.E., ${ }^{1}$ Olu S.I., ${ }^{1}$ Nnawuaku G.O., ${ }^{3}$ Ukoba 0. \\ ${ }^{1}$ Department of Human Anatomy, Faculty of Basic Medical Sciences Madonna University Nigeria \\ ${ }^{2}$ Department of Optometry, Faculty of Health Sciences, Madonna University Nigeria \\ ${ }^{3}$ College of Medicine, Virgen Milagrosa University Foundation, Phillipines \\ *Corresponding Author's E-mail: usaguwa@gmail.com
}

\begin{abstract}
The use of medicated glasses as visual aids was associated with the elderly,but in recent times the population of younger people using medicated glasses is alarming.Academic excellence is dependent on a number of factors of which clear comfortable binocular vision is dominant. Genetic, cultural and environmental factors play key roles in the prevalence and distribution of refractive errors. This study estimated the prevalence and distribution of the use of medicated glasses and refractive errors among students of Madonna University Nigeria, Elele campus, Rivers state. One thousand (1000) questionnaires were randomly distributed to $3^{\text {rd }}$ year undergraduate students in various departments in the college of medicine, including Anatomy, Physiology, Medicallab. Science, Optometry, Public health, and Pharmacy. $852(85.2 \%)$ of the questionnaires were retrieved and analyzed using simple percentages. Data collected included information on age, sex, state of origin, place of residence and presence of refractive errors. Our results reveal that North-west region had the highest prevalence of the use of medicated glasses among youths at $61.29 \%$.This is followed by south-west $(55.67 \%)$, southsouth $(36.27 \%)$, south-east $(31.67 \%)$, north-central $(19.67 \%)$ and north-east $(15.79 \%)$. On the average, the prevalence of the use of medicated glasses is $41.20 \%$ in the Southern part and $32.25 \%$ in the Northern part of Nigeria. The incidence of refractive errors also followed the same trend with North-west having (93.55\%), South-west $(50.51 \%)$, South-south $(32.88 \%)$, South-east $(27.67 \%)$, North central $(18.03 \%)$ and North-east $(15.79 \%)$. The highest occurring refractive error among the six geopolitical regions of Nigeria is myopia $(54 \%)$, followed by hyperopia $(21.01 \%)$, astigmatism $(15.30 \%)$ and presbyopia $(9.46 \%)$. This work represents the first attempt at having a comprehensive outlook at the statistics of the use of medicated glasses among Nigerian youths as well as the incidence of refractive errors among Nigerian youths.
\end{abstract}

Keywords: Refractive errors, Spectacles, Medicated glasses, Madonna University.

\section{INTRODUCTION}

The rate at which young people use medicated glasses today is alarming.It is a pointer to the possibility of rising incidence of refractive errors among Nigerian youths. This study provides data as to the frequency of the use of medicated glasses and the incidence of refractive errors among Nigerian youths.

People use glasses for corrective and cosmetic purposes.Recent studies done among children and young adults shows that refractive error has been the most prevalent ocular morbidity despite being to a very large extent correctable (Vinay and Shruthi, 2016, Prakash et al., 2015).Refractive errors vary over age, gender, race and ethnicity, level of education, social class and degree of urbanization (Prema 2011).

Reports show that 2.3 billion people worldwide have refractive errors, out of which about 500 million people mostly in developing countries have no access to proper checkup and correction. This has resulted in either 
Aguwa et al. 049

Table 1: Incidence of use of medicated glasses across the regions of Nigeria

\begin{tabular}{|c|c|c|c|}
\hline Region & $\begin{array}{c}\text { Total } \\
\text { Respondents }\end{array}$ & $\begin{array}{c}\text { Number using } \\
\text { medicated glasses }\end{array}$ & Percentage \\
\hline North West & 31 & 19 & $61.29 \%$ \\
\hline South West & 97 & 54 & $55.67 \%$ \\
\hline South South & 295 & 107 & $36.27 \%$ \\
\hline South East & 300 & 95 & $31.67 \%$ \\
\hline North Central & 122 & 24 & $19.67 \%$ \\
\hline North East & 19 & 3 & $15.79 \%$ \\
\hline
\end{tabular}

North-west and south-west had the highest incidences with $61.29 \%$ and $55.67 \%$ respectively. South east and south south play a middle position, having $31.67 \%$ and $36.27 \%$ respectively while the least incidences occur in the North central and East.

blindness or impaired vision, mostly (Holden et al., 2000).In Pakistan, $11.4 \%$ of the blindness is due to uncorrected refractive errors (National Committee for Prevention of Blindness, Ministry of Health 1994-98; P. 24). Studies indicate that refractive errors are mainly caused by genetic factors, others suggest an interplay between genetics and environmental factors (Feldkamper and Schaeffel, 2003). Apart from a positive history of wearing glasses in the family, environmental factors may include close work or near activity such as prolonged study hours, watching computers / television etc (Zadnik 1997, Saw et al., 2002). Myopia, the most studied refractive error is emerging as a global health problem, due to the costs associated with correction, and its associated pathology such as retinal tears, retinal detachments, and macular degeneration (Curtin, 1985). The prevalence of myopia varies in different parts of the world, being more prevalent in industrialized countries and cities compared to rural areas (Uzma et al., 2009).Other studies have found an association between socioeconomic status, education, academic achievement, and myopia (Teasdale and Goldschmidt, 1988; Rosner and Belkin, 1987, Parssinen, 1987).

In the US, the prevalence of myopia for people between the ages of 12 and 54, surged from $25 \%$ in the early 1970's to $42 \%$ by 2000 (Saw et al., 2002). In Taiwan and Singapore, myopia is found in approximately $30 \%$ of all children 6 and 7 years old, and increases to $80 \%$ in young adults (Saw, et al., 2002). The rapid increase in the prevalence of myopia strongly suggests that environmental factors are having a considerable influence on the development of myopia not explainable by the genetic model (Saw et al., 1996; Mutti et al., 1996).

In young children hyperopia and astigmatism may be found to be higher than myopia (Jimenez et al, 2012, Krishnamurthy et al., 2014).

\section{METHODS}

This study was carried out among $2^{\text {nd }}$ year students of Madonna University Nigeria, Elele campus. This population was chosen to ensure that whatever visual problems seen were not acquired within the period as a student but was already present before the individual came into the school. This was also ensured further by using only respondents who have used medicated glasses for at least five years. Meaning that usage must have commenced before studentship. One thousand (1000) questionnaires were randomly distributed to undergraduate students in various departments in the college of medicine, including Anatomy, Physiology, Medical laboratory Science, Optometry, Public health, and Pharmacy. Also, our distribution of students according to the states of Nigeria is based on residency, not place of origin.

As such, this work leans more towards environmental rather than genetic causes. Future analysis will consider the genetic factors. 930 of these questionnaires were retrieved $(93 \%)$. Out of that number, $864(86.4 \%)$ met with the conditions stated above and were used for the study. The remaining 66 were discarded. Data were analyzed using simple percentages. Data collected included information on age, sex, state of origin, place of residence with duration and presence of refractive errors.

\section{RESULTS}

Table 2 shows the incidence of use of refractive Northwest and south-west had the highest incidences of refractive errors with $61.29 \%$ and $50.51 \%$ respectively. North east and North central had the least incidences with $15.79 \%$ and $18.03 \%$ respectively. From table 3 , myopia had the highest occurrence with $54.21 \%$ of all 
050 J. Med. Med. Sci.

Table 2: Incidence of use of Refractive errors across the regions of Nigeria

\begin{tabular}{|c|c|c|c|}
\hline Region & $\begin{array}{c}\text { Total } \\
\text { Respondents }\end{array}$ & $\begin{array}{c}\text { Number using } \\
\text { medicated glasses }\end{array}$ & Percentage \\
\hline North West & 31 & 19 & $61.29 \%$ \\
\hline South West & 97 & 49 & $50.51 \%$ \\
\hline South South & 295 & 97 & $32.88 \%$ \\
\hline South East & 300 & 83 & $27.67 \%$ \\
\hline North Central & 122 & 22 & $18.03 \%$ \\
\hline North East & 19 & 3 & $15.79 \%$ \\
\hline
\end{tabular}

Table 3: Distribution of refractive error cases

\begin{tabular}{|l|c|c|c|}
\hline S/N & Refractive Error & Number & Percentage \\
\hline 1 & Myopia & 148 & $54.21 \%$ \\
\hline 2 & Hypermetropia & 77 & $28.21 \%$ \\
\hline 3 & Presbyopia & 5 & $1.83 \%$ \\
\hline 4 & Astigmatism & 43 & $15.75 \%$ \\
\hline & Total & 273 & $100 \%$ \\
\hline
\end{tabular}

Table 4: Distribution of Refractive errors across the regions of Nigeria

\begin{tabular}{|c|c|c|c|c|c|c|c|c|}
\hline \multirow[t]{2}{*}{ Region } & \multicolumn{2}{|c|}{ Myopia } & \multicolumn{2}{|c|}{ Hypermetropia } & \multicolumn{2}{|c|}{ Presbyopia } & \multicolumn{2}{|c|}{ Astigmatism } \\
\hline & $\mathrm{N}$ & $\%$ & $N$ & $\%$ & $N$ & $\%$ & $\mathrm{~N}$ & $\%$ \\
\hline South east & 47 & 31.76 & 21 & 27.27 & 1 & 20.00 & 11 & 25.58 \\
\hline South south & 52 & 35.13 & 33 & 42.86 & 0 & 0.00 & 9 & 20.93 \\
\hline South west & 27 & 18.24 & 7 & 9.09 & 2 & 40.00 & 11 & 25.58 \\
\hline North east & 3 & 2.03 & 0 & 0.00 & 0 & 0.00 & 0 & 0.00 \\
\hline North central & 11 & 7.43 & 9 & 11.69 & 1 & 20.00 & 5 & 11.63 \\
\hline North west & 8 & 5.41 & 7 & 9.09 & 1 & 20.00 & 7 & 16.28 \\
\hline Total & 148 & 100 & 77 & 100 & 5 & 100 & 43 & 100 \\
\hline
\end{tabular}

cases, followed by hypermetropia (28.21\%), Astigmatism $(15.75 \%)$ and presbyopia (1.83\%).

Table 4 shows the distribution of refractive errors across the 6 geopolitical zones of the country. Myopia was highest in south south and least in North east. South east and South west had high values. Hypermetropia was also highest in South south, followed by South east and North central. It was lowest South west and North West.

Table 5 shows the frequency of myopia according to individual states of Nigeria. This frequency however only represents a direct numerical counting, comparing a state with the total number of cases. So as expected, states in 
Aguwa et al. 051

Table 5: Distribution of Myopia according to states in Nigeria

\begin{tabular}{|l|l|l|l|l|l|l|l|}
\hline$S / N$ & State & Number & Percentage & $S / N$ & State & Number & Percentage \\
\hline 1 & Rivers & 27 & $18.12 \%$ & 11 & Ondo & 3 & $2.01 \%$ \\
\hline 2 & Lagos & 22 & $14.80 \%$ & 12 & Osun & 2 & $1.34 \%$ \\
\hline 3 & Delta & 21 & $14.10 \%$ & 13 & Bauchi & 2 & $1.34 \%$ \\
\hline 4 & Anambra & 15 & $10.10 \%$ & 14 & Kano & 2 & $1.34 \%$ \\
\hline 5 & Imo & 12 & $8.05 \%$ & 15 & Ebonyi & 1 & $0.67 \%$ \\
\hline 6 & Enugu & 11 & $7.38 \%$ & 16 & Oyo & 1 & $0.67 \%$ \\
\hline 7 & Abia & 9 & $6.04 \%$ & 17 & Borno & 1 & $0.67 \%$ \\
\hline 8 & FCT & 8 & $5.37 \%$ & 18 & Kogi & 1 & $0.67 \%$ \\
\hline 9 & Cross River & 5 & $3.36 \%$ & 19 & Sokoto & 1 & $0.67 \%$ \\
\hline 10 & Kadunna & 4 & $2.68 \%$ & 20 & Katsina & 1 & $0.67 \%$ \\
\hline & & & & & Total & 149 & $100 \%$ \\
\hline
\end{tabular}

Table 6: Distribution of Hypermetropia according to states in Nigeria

\begin{tabular}{|l|l|l|l|l|l|l|l|}
\hline$S / N$ & State & Number & Percentage & $S / N$ & State & Number & Percentage \\
\hline 1 & Rivers & 19 & $24.67 \%$ & 10 & Kogi & 2 & $2.60 \%$ \\
\hline 2 & Delta & 8 & $10.40 \%$ & 11 & Kano & 2 & $2.60 \%$ \\
\hline 3 & Imo & 7 & $9.09 \%$ & 12 & Cross River & 1 & $1.30 \%$ \\
\hline 4 & Anambra & 6 & $7.79 \%$ & 13 & Sokoto & 1 & $1.30 \%$ \\
\hline 5 & Edo & 6 & $7.79 \%$ & 14 & Plateau & 1 & $1.30 \%$ \\
\hline 6 & Lagos & 6 & $7.79 \%$ & 15 & Kadunna & 1 & $1.30 \%$ \\
\hline 7 & FCT & 6 & $7.79 \%$ & 16 & Niger & 1 & $1.30 \%$ \\
\hline 8 & Abia & 5 & $6.49 \%$ & 17 & Osun & 1 & $1.30 \%$ \\
\hline 9 & Enugu & 4 & $5.19 \%$ & & & 77 & $100 \%$ \\
\hline
\end{tabular}

Table 7: Distribution of Presbyopia according to states in Nigeria

\begin{tabular}{|l|l|c|c|}
\hline S/N & State & Number & Percentage \\
\hline 1 & Lagos & 2 & $50 \%$ \\
\hline 2 & Anambra & 1 & $25 \%$ \\
\hline 3 & FCT & 1 & $25 \%$ \\
\hline & Total & 4 & $100 \%$ \\
\hline
\end{tabular}

the south will have more frequency than those in the North as the University is located in Rivers state, South south part of the country. Table 6 shows the frequency of hypermetropia by states. As in above, states in the southern part of the country had the highest frequency by number. Table 7 shows the distribution of presbyopia according to states. Table 8 shows the distribution of Astigmatism according to states in Nigeria. 
052 J. Med. Med. Sci.

Table 8: Distribution of Astigmatism according to states in Nigeria

\begin{tabular}{|l|l|l|l|l|l|l|l|}
\hline$S / N$ & State & Number & Percentage & $S / N$ & State & Number & Percentage \\
\hline 1 & Lagos & 11 & $25.58 \%$ & 8 & Katsina & 2 & $2.33 \%$ \\
\hline 2 & Imo & 7 & $16.28 \%$ & 9 & Abia & 1 & $2.33 \%$ \\
\hline 3 & Delta & 6 & $13.95 \%$ & 10 & Anambra & 1 & $2.33 \%$ \\
\hline 4 & FCT & 5 & $11.63 \%$ & 11 & Osun & 1 & $2.33 \%$ \\
\hline 5 & Enugu & 3 & $6.98 \%$ & 12 & Plateau & 1 & $2.33 \%$ \\
\hline 6 & C. River & 2 & $4.65 \%$ & 13 & Kadunna & 1 & $2.33 \%$ \\
\hline 7 & Rivers & 2 & $4.65 \%$ & & & & $100 \%$ \\
\hline
\end{tabular}

\section{DISCUSSION}

Our results reveal that out of the total of 864 respondents used for this study, $302(37.03 \%)$ use medicated glasses and $31.60 \%(273)$ had a refractive error. This is similar to the $37.39 \%$ report by Prema 2011 in a study carried out in India.Our results reveal that North-west region had the highest prevalence of the use of medicated glasses among youths at $61.29 \%$. This is followed by south-west $(55.67 \%)$, south-south $(36.27 \%)$, south-east $(31.67 \%)$, north-central (19.67\%) and north-east (15.79\%).

On the average, the prevalence of the use of medicated glasses is $41.20 \%$ in the Southern part and $32.25 \%$ in the Northern part of Nigeria. The incidence of refractive errors also followed the same trend with Northwest having (61.29\%), South-west $(50.51 \%)$, Southsouth $(32.88 \%)$, South-east $(27.67 \%)$, North central $(18.03 \%)$ and North-east (15.79\%). The highest occurring refractive error among the six geopolitical regions of Nigeria is myopia $(54.21 \%)$, followed by hyperopia $(28.21 \%)$, astigmatism $(15.75 \%)$ and presbyopia (1.83\%). This is similar to the report of Adeoti and Egbewale, 2008 in a study carried out in Ado ekiti where myopia constituted 39.33\%, hyermetropia $23.33 \%$ and astigmatism $21.80 \%$. The increasing incidence of refractive errors and consequent use of medicated glasses may be associated with the longer time our youth spend reading books, working on the computer and watch television according to the report of Prema 2011.

This may explain why the incidence was higher in more developed cities and states of the country than the less developed places.

\section{CONCLUSION}

Our results suggests that there is a rise in the incidence of refractive errors among our youths, leading to increase in the use of medicated glasses, a phenomenon that was more common among the elderly in our society.

\section{RECOMMENDATION}

- We therefore recommend that government and its agencies should pay attention to those environmental factors that predispose our youths to visual impairments.

- This study can be extended to specific regions of the country, especially those with observed high incidence from this study.

- Also, attention should be paid to sexual disparity in the manifestation of these refractive errors.

\section{REFERENCES}

Adeoti CO, Egbewale BE (2008). Refractive errors in Mercyland Specialist Hospital, Osogbo, Western Nigeria. Niger postgrad Med J., 15: 116-9.

Dandona R, Dandona L, Naduvilath TJ, Srinivas M, McCarty CA, Rao GN (1999). Refractive errors in an urban population in southern India: The Andhra Pradesh Eye Disease Study. Investig Ophthalmol and Vis Sci., 40: 2810-18.

Feldkamper M, Schaeffel F (2003). Interactions of genes and environment in myopia. Dev Ophthalmol.; 37: 34-49.

Holden BA, Sulaiman S, Knox K (2000). The Challenge of Providing Spectacles in the Developing World. J. Community Eye Health; 13 (33): 9-10.

Mutti DO, Mitchell GL, Moeschberger ML, Jones LA, Zadnik K (2002).

Parental myopia, near work, school achievement, and children's refractive error. Invest Ophthalmol Vis Sci. Dec; 43 (12): 3633-40.

National Committee for Prevention of Blindness, Ministry of Health, Special Education and Social Welfare, Islamabad, Pakistan, National Programme for Prevention of Blindness: First five year Plan 1994-98; P. 24.

Prema N (2011). Causing factors of refractive error in children:heredity or environment. Indian J.Sci. Technol. Vol.4, No.12, Dec.

Saw SM, Zhang MZ, Hong RZ, Fu ZF, Pang MH, Tan DT. Near-work activity, night lights, and myopia in the Singapore-China study. Arch Ophthalmol. 2002 May;120 (5): 620-7

Zadnik K, Satariamo WA, Mutti DO (1994). The effects of parental H/o myopia on children eye size. JAMA; 271: 1323-1327.

Zadnik K. The Glenn A. Fry Award Lecture (1995). Myopia development in childhood. Optom Vis Sci. 1997 Aug; 74 (8): 603-8. 
Aguwa et al. 053

\section{APPENDIX}

\section{Questionnaire}

This research work is been carried out in Madonna university, Elele campus on Frequency of medicated glasses in Nigeria. Please kindly respond to the questions as genuinely as possible. Be assured that your confidentiality shall be respected. As the information given cannot be traced to you in any way. All information is strictly for research purposes. Thank you for your cooperation.

Section A: Personal information (please tick the appropriate box).

1. Sex: $M$

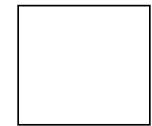

2. Age:

$15-20$
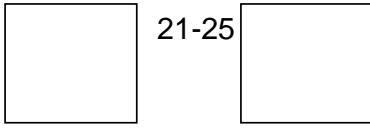

$\mathrm{F}$

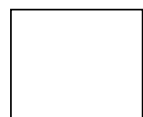

3. State of origin:

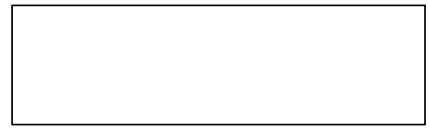

4. Where have you resided for the most part of your life?

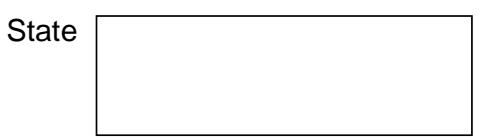

City/ Town

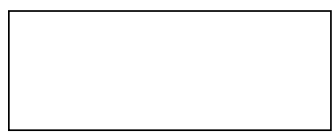

5. For how long have you or did you stay there?

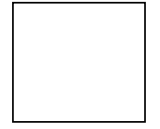

\section{Section B:}

1. Do you use glasses? Yes

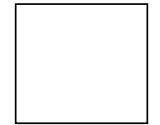

No

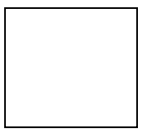

2. Are your glasses medicated?

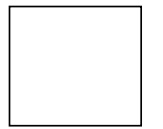

No

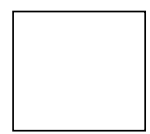

3. Please specify the type.

A. Myopia (Shortsightedness)

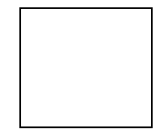

B. Hypermetropia (long-sightedness)

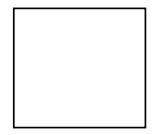

C. Presbyopia

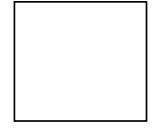

D. Astigmatism

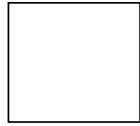


E. Others (please specify)

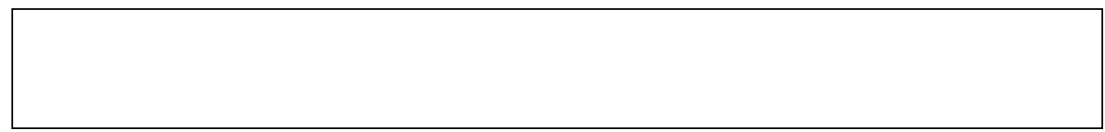

4. How long have you used it?

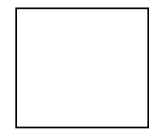

Years

5. How many siblings do you have?

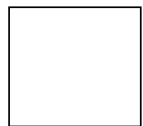

6. How many of them use glasses?

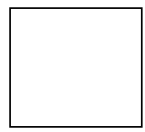

